\title{
An In Vivo and In Vitro Assessment of the Probiotic Potentials of Indigenous Halotolerant Bacteria on Growth Performance and Digestive Enzymes of White Leg Shrimp (Litopenaeus vannamei) in High-Salinity Waters
}

\author{
Maryam Mirbakhsh ${ }^{D},{ }^{1}$ Babak Ghaednia ${ }^{(D)}{ }^{1}$ and Akram Sadat Tabatabaee Bafroee $\mathbb{D}^{2}$ \\ ${ }^{1}$ Iranian Fisheries Science Research Institute, Agricultural Research Education and Extension Organization (AREEO), Tehran, Iran \\ ${ }^{2}$ Department of Biology, East Tehran Branch, Islamic Azad University, Tehran, Iran
}

Correspondence should be addressed to Maryam Mirbakhsh; maryam.mirbakhsh@gmail.com and Babak Ghaednia; babak.ghaednia@gmail.com

Received 26 October 2021; Accepted 18 February 2022; Published 7 March 2022

Academic Editor: Liqiao Chen

Copyright () 2022 Maryam Mirbakhsh et al. This is an open access article distributed under the Creative Commons Attribution License, which permits unrestricted use, distribution, and reproduction in any medium, provided the original work is properly cited.

\begin{abstract}
The present study was aimed at evaluating Bacillus subtilis subsp. inaquosorum strain IS02 (B.s.i. IS02; GenBank accession number: JN856456.1) to determine the growth kinetics of antimicrobial metabolite production in different ranges of environmental factors, such as salinity $(15-55 \%), \mathrm{pH}(5-9)$, and temperature $\left(30-40^{\circ} \mathrm{C}\right)$; to evaluate the lifespan of antimicrobial metabolites in different ranges of salinity (0-57\%o), $\mathrm{pH}(2-12)$, and temperature $\left(35-121^{\circ} \mathrm{C}\right)$; and to investigate the effect of B.s.i. IS02 as an additive to functional feed on the digestive activity of Litopenaeus vannamei under high-salinity conditions. Based on the present findings, the bacterium maintained its antimicrobial properties up to $45 \%$ salinity $\left(10729.93 \pm 23.93 \mathrm{AU} \mathrm{ml} l^{-1}\right)$. There was no significant difference in the antimicrobial activity of metabolites at $35^{\circ} \mathrm{C}$ and $40^{\circ} \mathrm{C}$ $(p>.05)$. In the experimental trials, the shrimp postlarvae were fed different concentrations of B.s.i. IS $02\left(10^{6}, 10^{7}\right.$, and $10^{8}$ CFU kg ${ }^{-1}$ diets) under high-salinity $(>55 \%$ ) conditions. The activity of digestive enzymes, amylase, lipase, and protease in the probiotic-fed shrimp postlarvae was significantly higher than that of the control group $(p<.05)$. The present findings revealed that B.s.i. IS02 maintained the antimicrobial metabolite production, retained the antibacterial lifespan in high-salinity waters, and improved the growth and digestive enzyme activities of shrimps.
\end{abstract}

\section{Introduction}

The shrimp industry is one of the leading aquaculture industries around the world, which is ranked among the top sources of national revenue for some countries. Viral and bacterial diseases, such as white spot syndrome, vibriosis, and acute hepatopancreatic necrosis disease (AHPND), have significantly reduced the production of shrimp $[1,2]$. On the other hand, supplementary feeds account for $40-70 \%$ of the total cost of shrimp farming [3]; following diseases, they are the second most important challenge facing shrimp farming around the world. Currently, some preventive measures, such as the use of antibiotics, antimicrobial disinfec- tants, and chemical additives, are being taken to improve shrimp farming [4], resulting in the increased emergence of multidrug-resistant strains of bacteria in shrimp and the possible exposure of human consumers to antibiotic residues [5]. Therefore, comprehensive research is needed to discover new antimicrobials with high capacity and minimal residual accumulation in the shrimp tissue as environment-friendly alternatives to common antibiotics for the management of shrimp diseases. One of the effective alternatives is to use probiotics $[6,7]$. According to several studies, application of various bacterial strains as probiotics in shrimp farms, particularly Litopenaeus vannamei, which is one of the most important shrimp species, has a high economic value. These 
probiotics include Lactobacillus plantarum, Bacillus licheniformis, Bacillus subtilis, and purple nonsulfur bacteria obtained from pickled cabbage, shrimp gut, and shrimp ponds, as they seem to contribute to the improvement of shrimp weight and growth rate (GR), prevention of infection, and improvement of the immune system and survival rate [8-13]. Probiotics develop resistance to shrimp diseases by hindering pathogen colonization through competition and antimicrobial metabolite production (e.g., bacteriocins, hydrogen peroxide, and organic acids), which inhibits the growth of pathogens and improves shrimp health [5, 7]. The agricultural community and consumers have shown increasing interest in functional feeds, which contain sufficient amounts of bioactive compounds, particularly probiotics, and confer benefits to shrimp production; they also provide nutrients to consumers through specific dietary components [14].

Due to the high evaporation rate in some regions with a shrimp farming industry, including Southern Iran and Saudi Arabia, the salt concentrations in ponds gradually increase during summer. Therefore, one of the problems of shrimp farming is the inadequate effectiveness of nonhalotolerant probiotic bacteria under high-salinity conditions $[15,16]$. The current study was aimed at examining the characteristics of Bacillus subtilis subsp. inaquosorum strain IS02 (B.s.i. IS02), as a novel indigenous halotolerant bacterium which can maintain the growth and production of antibacterial metabolites under the conditions of high salinity and high water temperature, and at investigating its efficiency as an additive in the growth performance and digestive enzymes of $L$. vannamei.

\section{Materials and Methods}

For in vitro experiments, pure cultures of the probiont Bacillus subtilis subsp. inaquosorum IS02 (B.s.i. IS02) and Vibrio harveyi IS01 (PTCC 1755) (indicator bacterium) which have been previously isolated from shrimp farming sites of Bushehr in Southwest of Iran and diseased shrimp from hatchery unit in Iran Shrimp Research Center were applied, respectively $[17,18]$. Molecular identification of the isolates by $16 \mathrm{~S}$ rDNA gene sequencing has been formerly explained in detail [17]. To prepare the functional feed for L. vannamei postlarvae, the commercial feed (with crude protein content $38 \%$, fat content $9 \%$, crude fiber $3 \%$, ash content $14 \%$, and moisture content 10\%) was purchased from Havoorash factory (Bushehr, Iran) and enriched with freeze-dried B.s.i. IS02 probiotic (Tak cell ${ }^{\mathrm{TM}}$, Takgene factory) at a dose of $10^{13} \mathrm{CFU} \mathrm{Kg}$, and corn starch (2\%) as a binder. All materials and culture media were purchased from Merck (Darmstadt, Germany).

\subsection{In Vitro Evaluation of the Effect of Different Salinity Concentrations, Temperatures, and $\mathrm{pHs}$ on Antimicrobial Metabolite Production by B.s.i. ISO2}

2.1.1. Preculture Preparation. To prepare the inoculum, a $50 \mathrm{ml}$ Tryptice Soy Broth supplemented with $2.5 \%$ salinity natural seawater (TSB-2.5\% Sea) was inoculated with a loop- ful of single bacterial colony and then incubated in the shaker incubator (JSSI200CL JSR Inc., Korea) at $150 \mathrm{rpm}$ and $30^{\circ} \mathrm{C}$ until the optical density (OD) reaches one McFarland $\left(\mathrm{OD}_{600}=0.2, \mathrm{UV}-\mathrm{V}\right.$ is Spectrophotometer 6800 Jenway Inc., England).

\subsubsection{Fermentation Process under Various Ecological} Parameters (Salinity, $\mathrm{pH}$, and Temperature). To evaluate the effect of different salinity concentrations and $\mathrm{pHs}$ on antimicrobial metabolite production by B.s.i. IS02, first $5 \%$ of prepared preculture was transferred into TSB media with different salinity concentrations $(15,25,35,45$, and $55 \%$ o seawater) and TSB-2.5\% media with various $\mathrm{pHs}(5,6,7$, 8 , and 9) adjusted by $\mathrm{HCl}$ and $\mathrm{NaOH}$ (1 M) individually, and then, all cultures were incubated in a shaking incubator at $150 \mathrm{rpm}$ and $30^{\circ} \mathrm{C}$. As for determining the effect of different temperatures on the amount of antimicrobial metabolite production, the inoculated TSB $-2.5 \%$ media with B.s.i. IS02 were incubated separately at $30^{\circ} \mathrm{C}, 35^{\circ} \mathrm{C}$, and $40^{\circ} \mathrm{C}$ in a shaking incubator at $150 \mathrm{rpm}$. Cultures were evaluated for antimicrobial metabolite production after 48 hours, according to the results obtained from previous studies [18-20].

2.1.3. Evaluation of the Antimicrobial Metabolite Production by Agar Well Diffusion Method (AWDM). In order to determine the antimicrobial metabolite production by B.s.i. IS02 grown in the abovementioned conditions, briefly, $1 \mathrm{ml}$ of each culture was removed and centrifuged at $9500 \mathrm{rpm}$ and $4^{\circ} \mathrm{C}$ for 4 min (3-16PK, Sigma Inc., Germany), and then, the resultant cell-free supernatants (CFSs) were passed through a $0.45 \mu \mathrm{L}$ Millipore filter (Millipore, MS ${ }^{\circledR} \mathrm{PES}$ syringe filter, USA) and $\mathrm{pH}$ adjustment was carried out as necessary. Muller-Hinton agar containing $2.5 \%$ seawater (MHB-2.5\% Sea) was inoculated with $200 \mu \mathrm{L}$ of standardized inoculum of $V$. harveyi $\left(\mathrm{OD}_{600}=0.5\right)$. Then, $6 \mathrm{~mm}$ diameter wells were punched and CFSs were poured into wells ( $100 \mu \mathrm{l} /$ well). After a 48 -h incubation at $30^{\circ} \mathrm{C}$, the diameter of the inhibition zones was measured by using a digital caliper [21]. All experiments were carried out in triplicate to ensure the feasibility and reproducibility.

2.1.4. Antimicrobial Metabolite Activity Assay. To quantitatively assess the antimicrobial activity of metabolites produced by B.s.i. IS02, twofold dilutions of CFSs were prepared and their growth inhibition was measured against $V$. harveyi as indicator strain via AWDM as mentioned previously. Then, the quantitative assay was calculated by drawing the standard curve based on the amount of growth and sample dilution and the following equation [22]:

$$
\mathrm{R}=\mathrm{a}+\mathrm{blog}(\mathrm{d}),
$$

where $R$ and $d$ are defined as the diameter of inhibition zone, the volume of inoculated sample per well, and the sample volume, $a$ is the $y$ intercept and $b$ is the slope, accordingly. 
The total activity of each sample was calculated according to the following formula:

$$
\text { Total activity }\left(\mathrm{AU} \mathrm{m}^{-1}\right)=(1000 / \mathrm{V}) \mathrm{D} 10^{(\mathrm{R} / \mathrm{b})} \text {, }
$$

where $V$ and $D$ are introduced as the sample volume and dilution factor, respectively. The total activity was expressed in an arbitrary unit $\left(\mathrm{AU} \mathrm{ml}^{-1}\right)[22,23]$.

2.1.5. Evaluating the Lifespan of Antimicrobial Metabolites at Different $p H s$, Temperatures, and Salinity Concentrations. To this purpose, the B.s.i. IS02 preculture was prepared as mentioned in Section 2.1.1 and centrifuged at $9500 \mathrm{rpm}$ and $4^{\circ} \mathrm{C}$ for $4 \mathrm{~min}$ to obtain the CFS containing antimicrobial metabolites. The resultant CFS was filter sterilized and treated with various salinity concentrations $(0,20,23,30$, $35,42,50$, and 57\%o) and pHs (5, 6, 7, 8, and 9) for $120 \mathrm{~min}$, separately. In addition, different incubation temperatures of $35,40,45,55,65,75,85$, and $100^{\circ} \mathrm{C}$ for 10 $20 \mathrm{~min}$ and also autoclave of CFS were conducted. To prevent the CFS evaporation, sterile liquid paraffin was added. Then, the antimicrobial activity of treated CFSs against $V$. harveyi was evaluated by AWDM and the diameter of the inhibition zones of each treatment and its replications were measured and recorded by a digital caliper [24, 25].

\subsection{In Vivo Evaluation of Enriched Dietary Supplement with B.s.i. ISO2 on L. vannamei}

\subsubsection{Preparation of Probiotic Dietary Supplement} Containing B.s.i. IS02. For this purpose, certain amounts of the aforementioned probiotic powder were dissolved in seawater to reach the final doses of $10^{6}, 10^{7}$, and $10^{8} \mathrm{CFU} \mathrm{Kg}{ }^{-1}$ separately and aerated for 30 minutes for spore germination. Commercial shrimp feed was spread on a tray and enriched with B.s.i. IS02 at the final doses separately through spraying method. After that, the dissolved corn starch (2\%) was sprayed on them. For determining the amount of the probiotic in the feed, briefly, $1 \mathrm{~g}$ of each treated feed was randomly sampled and serially 10-fold diluted in phosphate-buffered saline solution (PBS; $\mathrm{pH} 7.2$ ) and $1 \mathrm{ml}$ of each dilution was then spread on mannitol-egg yolk-polymyxin agar (MYP agar, Merck, Germany) by spread plate technique, incubated at $30^{\circ} \mathrm{C}$, and counted bacteria colonies, in order to estimate the probiotic concentration $\left(10^{6}, 10^{7}\right.$, and $\left.10^{8} \mathrm{CFU} \mathrm{Kg}{ }^{-1}\right)$ in feed [26]. The final compositions were transferred to the freezer in plastic containers.

2.2.2. Experimental Design. Postlarvae of healthy L. vannamei were transported from the Bandargah Station to the Shrimp Research Center in Bushehr (Iran). They had no clinical signs of disease as confirmed by morphological examination and standard microbiological techniques. Shrimp postlarvae (450 pieces) were weighted, randomly distributed in 12 polyethylene tanks containing $300 \mathrm{~L}$ seawater, and acclimatized for 7 days prior to the experiment. 4 trials were conducted in triplicates (30 pieces of shrimp per tank) indoor. Control treatments were administrated with either feed only (TC), feed supplemented with $10^{6} \mathrm{CFU} \mathrm{Kg}^{-}$ ${ }^{1}$, and $10^{7} \mathrm{CFU} \mathrm{Kg}{ }^{-1}$ and $10^{8} \mathrm{CFU} \mathrm{Kg}^{-1}$ B.s.i IS02, respectively, named T1, T2, and T3 group. The average weight of shrimp post larvae was $1.06 \pm 0.05 \mathrm{~g}$ at the time of stocking. According to their average weight, they were fed with their specific diets three times a day at 5\% of the body weight for 40 days. During the trial, the temperature and salinity level of the water were recorded daily. Additionally, the average water temperature and the average water salinity were maintained at $33.4 \pm 0.12^{\circ} \mathrm{C}$ and $55 \pm 1 \%$, respectively, and $\mathrm{pH}$ fluctuations were determined $7.34 \pm 0.21$ in the tanks. Unconsumed feed and fecal matter were removed if necessary.

2.2.3. Measuring of Growth Indices. At the end of the experiment (40 days), the Final Weight (FW), Specific Growth Rate (SGR), Relative Growth Rate (RGR), Food Conversion Rate (FCR), and Survival Rate (SR) of shrimp were calculated as follows [27]:

The Specific Growth Rate (SGR \%; \%/day) was calculated as

$$
\frac{\operatorname{Ln}[\text { Final Weight }(g)]-\operatorname{Ln}[\operatorname{Initial} \text { weight }(g)]}{40 \text { day }} \times 100 \text {. }
$$

The Relative Gain Rate (RGR; \% g/shrimp) was calculated as

$$
\frac{\text { Final weight }(g)-\text { Initial weight }(g)}{\text { Initial weight }(g)} \times 100 \text {. }
$$

The FCR was calculated as

$$
\frac{\text { Food consumed }(g)}{\text { Final weight }(g)-\text { Initial weight }(g)} \text {. }
$$

The SR was calculated as

Number of shrimp at the end of experiment (pieces)

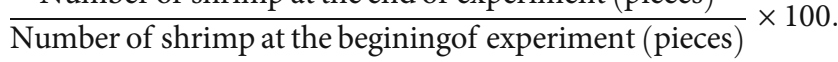

2.2.4. Digestive Enzyme Assay. At the end of the experiment, 16 shrimps were randomly sampled from each trial (TC, T1, T2, and T3 groups) four hours after the morning feed. The entire intestine of the shrimp was dissected, pooled, weighted $(0.2 \mathrm{~g})$, and homogenized with $500 \mu \mathrm{L}$ of chilled phosphate-buffered saline solution (PBS; pH 7.2), using an ultrasonic homogenizer (UP200H, Hielscher, Germany) in the presence of ice for two minutes. The homogenate was then centrifuged at $5,000 \mathrm{~g}$ for 15 minutes at $4^{\circ} \mathrm{C}$ under sterile conditions [28]. The recovered supernatants were frozen at $-70^{\circ} \mathrm{C}$. The supernatant of every sample was assayed in duplicate.

The amylase activity was measured according to Bernfeld's method (1955) by using soluble starch as a substrate reacting with 3,5-dinitrosalicylic acid (DNS) [29]. The total protease activity was examined according to the modified version of a technique proposed by Anson [30], using casein as a substrate, reacting it with Folin's reagent. The total 


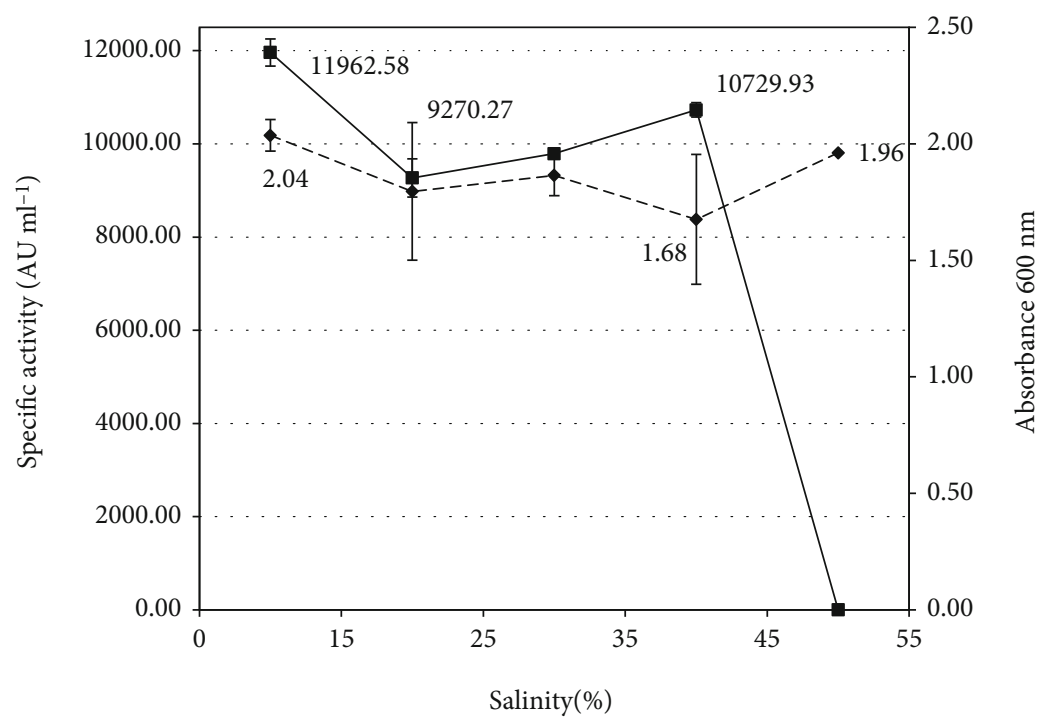

$$
\begin{aligned}
& \hookrightarrow \mathrm{AU} \\
& -\bullet \mathrm{OD}
\end{aligned}
$$

(a)

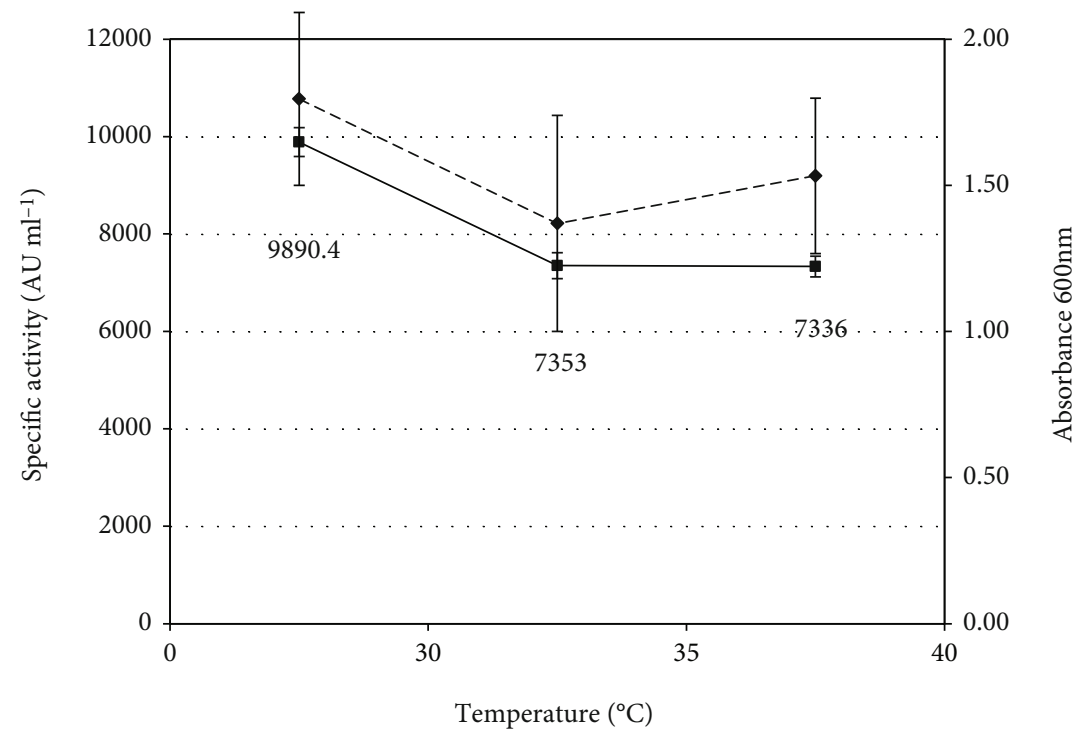

$$
\begin{aligned}
& -\mathrm{AU} \\
& -\bullet \mathrm{OD}
\end{aligned}
$$

(b)

Figure 1: Continued. 


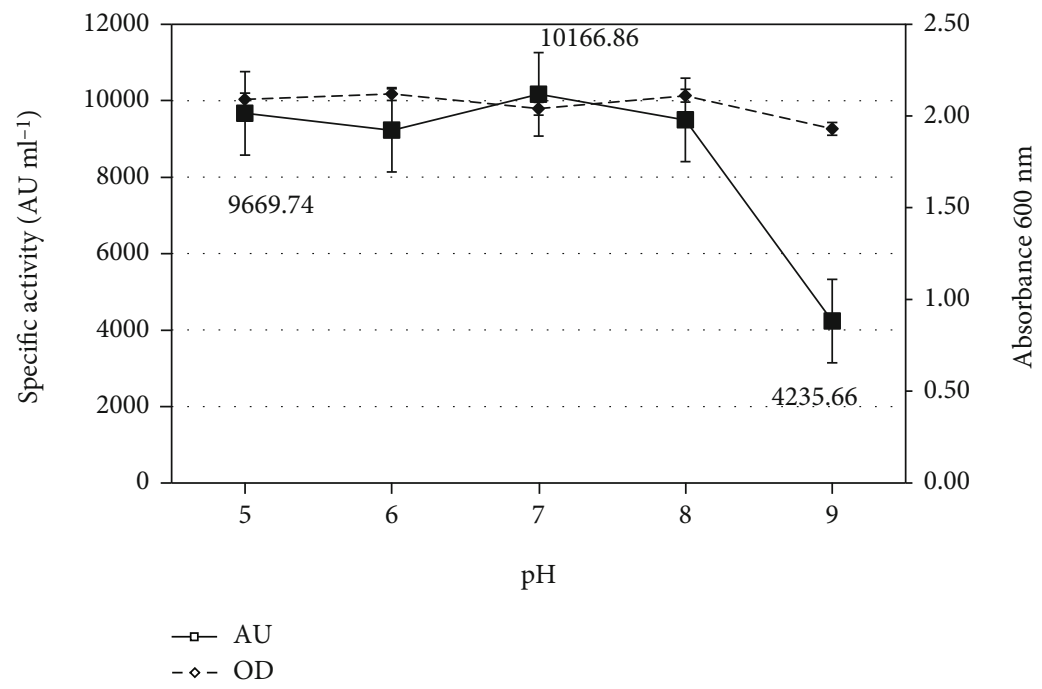

(c)

Figure 1: $(\mathrm{a}-\mathrm{c})$ Antimicrobial activity $\left(\mathrm{AU} \mathrm{ml}^{-1}\right)$ of B.s.i. IS02 metabolites and its growth rate at different salinities, temperatures, and pHs. Each number is the mean of three samples taken from different treatments.

protein activity was measured based on bovine serum albumin as standard by the Bradford method [31].

The lipase activity was measured by the colorimetric method, depending on the cleavage of $\mathrm{p}$-nitrophenyl palmitate (pNPP) at $\mathrm{pH}$ of 8.0 [32]. The enzyme activity was also measured as change in absorbance using a spectrophotometer (Jenway Lnc., England) and expressed as specific activity (U mg- $\left.{ }^{1}\right)$.

2.3. Statistical Analysis. The results of this research were analyzed by the one-way ANOVA and Duncan post hoc tests to determine the differences $(p<.05)$ between testing groups. All statistics were performed with Predictive Analytics Software (PASW), version 22 (IBM $^{\circledR}$ SPSS $^{\circledR}$, USA) and excel software, version 2016.

\section{Results}

\subsection{In Vitro Results}

3.1.1. The Effect of Different Salinity Concentrations, pHs, and Temperatures on Antimicrobial Metabolite Production by B.s.i. IS02. (Figure 1(a)-1(c)) represent the results of antimicrobial metabolite production by B.s.i. IS02 under different salinity concentrations, $\mathrm{pHs}$, and temperatures. Based on the results, the highest antimicrobial activity of B.s.i. IS02 was obtained at $15 \%$ o salinity $(11962.58 \pm 28.20$ $\mathrm{AU} \mathrm{ml}^{-1}$ ), while its properties were well maintained up to $45 \%$ o $\left(10729.93 \pm 23.93 \mathrm{AU} \mathrm{m}^{-1}\right)$ salinity. B.s.i. IS02 showed growth at all salinity concentrations and the highest growth was in 55\%o (Figure 1(a)). There was a significant difference between the antimicrobial activity of IS02 metabolites at all salinity concentrations $(p<.05)$ (Figure $2(a))$. Antimicrobial metabolite activity at $30^{\circ} \mathrm{C}\left(9890.4 \pm 294.95 \mathrm{AU} \mathrm{ml}^{-1}\right)$ was significantly higher than those obtained at $35^{\circ} \mathrm{C}$ and $40^{\circ} \mathrm{C}$ $(p<.05)$ (Figure 1(b) and the same trend was observed for bacterial growth. However, at all three temperatures studied, bacterial production of antimicrobial metabolites occurred. There was no significant difference between the antimicrobial activity of bacterial metabolites at temperatures of $35^{\circ} \mathrm{C}$ and $40^{\circ} \mathrm{C}(p>0.05)$ (Figure $\left.2(b)\right)$. The highest antimicrobial activity was observed at $\mathrm{pH} 7 \quad(10166.34 \pm 86.52$ $\left.\mathrm{AU} \mathrm{m}^{-1}\right)$ and the lowest was at pH9 (4235.66 \pm 97.83 $\mathrm{AU} \mathrm{m}^{-1}$ ) (Figure 1(c)). The antimicrobial activity of the bacterium at $\mathrm{pH} 7$ and other tested $\mathrm{pHs}$ has a significant difference $(p<.05)$ (Figure 2(c)). Growth had been seen in all tested acidity ranges (Figure 1(c)) but the growth rate at $\mathrm{pH} 9$ was significantly lower than other $\mathrm{pH}$ ranges $(p<.05)$.

3.1.2. Antibacterial Metabolite Lifespan at Different Salinity Concentrations, $\mathrm{pHs}$, and Temperatures. The lowest reduction in the antimicrobial lifespan of metabolites was in salinity of $0,23 \%$, and $57 \%$. Antibacterial properties on $V$. harveyi in all tested salinity range were well-maintained (Figure 3(a)). The lifespan rate of B.s.i. IS02 antimicrobial activity at 40 and $85^{\circ} \mathrm{C}$ after 10 minutes was $76.62 \%$ and $72.41 \%$, respectively, which was lower than other temperatures but reached the highest level at $75^{\circ} \mathrm{C}$. It also reached zero at 100 and 121 degrees after 10 minutes (Figure 3(b)). The antimicrobial activity of this bacterium was higher at 40,55 , and $75^{\circ} \mathrm{C}$ than at 45 and $65^{\circ} \mathrm{C}$ and reached zero at 100 and $121^{\circ} \mathrm{C}$ after $20 \mathrm{~min}$ (Figure $3(\mathrm{~b})$ ). The lowest lifespan of the antimicrobial metabolite on $V$. harveyi was at acidic $\mathrm{pH}=2$ and alkaline $\mathrm{pH}=12$ (Figure 3(c)).

3.2. In Vivo Results. In all of the experimental trials in tanks, the mean water temperature during the trial period was kept $33.9 \pm 0.42^{\circ} \mathrm{C}$ and the average water salinity was measured and maintained at $56 \pm 0.1 \%$, pH fluctuations were $7.39 \pm$ 0.269 .

3.2.1. The Effect of B.s.i. ISO2 on Growth Performances in L. vannamei. The highest SGR and RGR were in the dose of $10^{8} \mathrm{CFU} \mathrm{Kg}^{-1}$ (T3), which showed a significant difference 


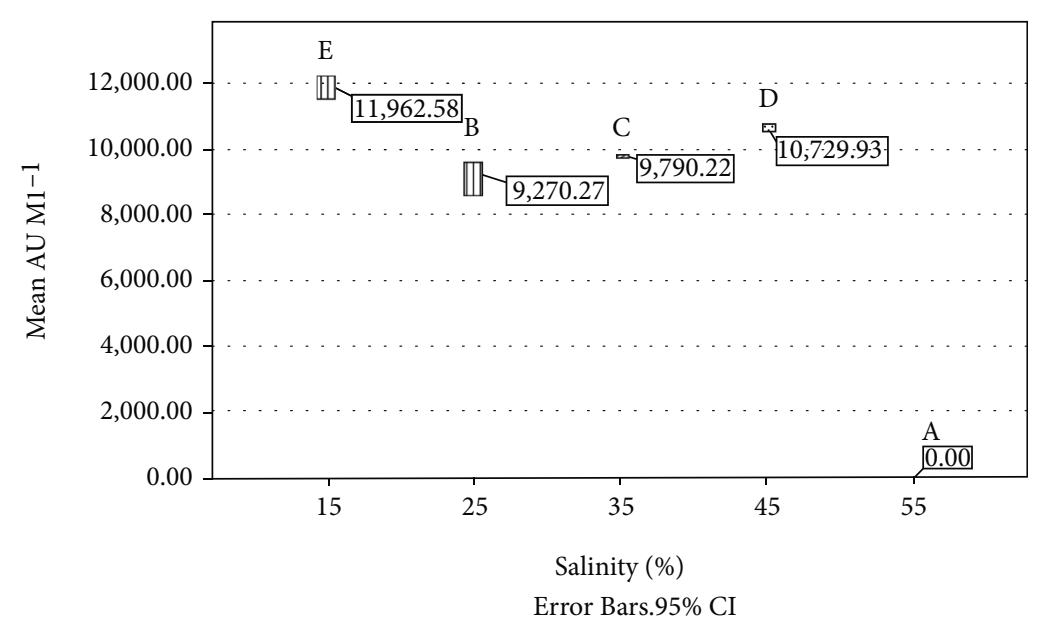

(a)

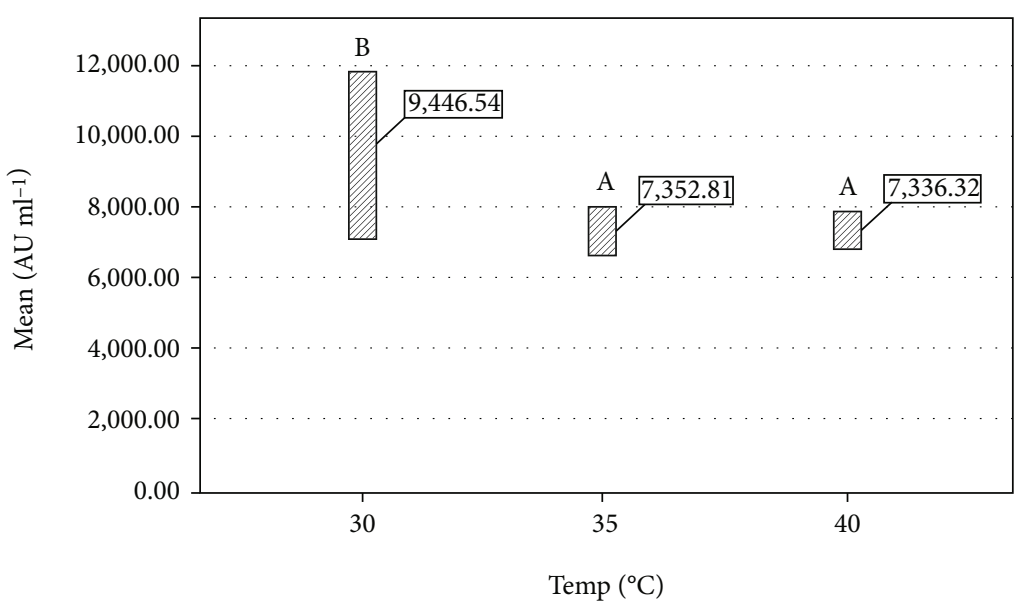

(b)

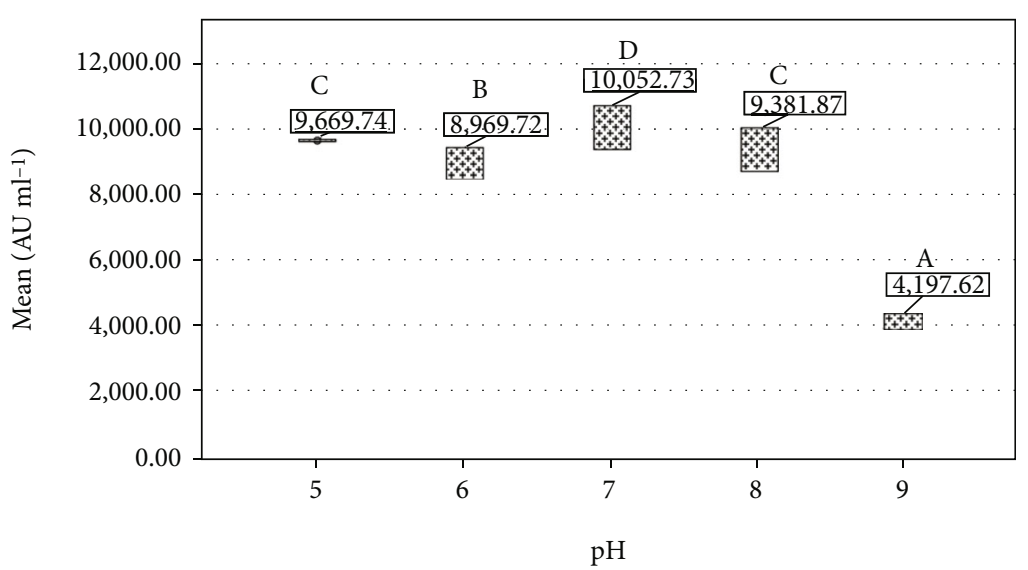

(c)

FIGURE 2: (a-c) Classification of B.s.i. IS02 antimicrobial activity by different (a) salinity groups (b) temperature groups, and (c) pHs groups at $95 \%$ confidence level.

to the control group $(p<.05)$. The survival rate of all the treatments was significantly different from the control group $(p<.05)$. According to the results, probiotic diets had a significant effect on reducing the FCR compared to the control $(p<.05)$. The lowest FCR was observed in T3 (Table 1).
3.2.2. Effect of B.s.i. ISO2 on the Activity of Digestive Enzymes of L. vannamei. After 40 days of culture and feeding shrimp with probiotic diets, amylase, protease, and lipase activity in T3 was significantly higher than other treatments $(p<.05)$, (Figures 4(a), 4(b), and 4(c)). 


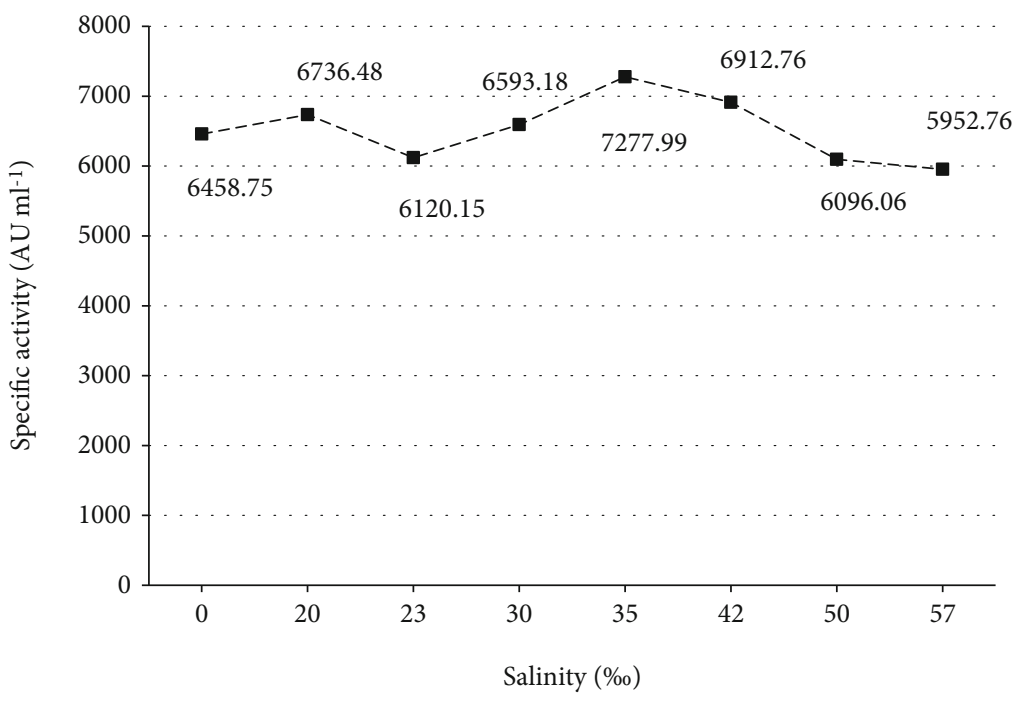

$-\mathrm{AU}$

(a)

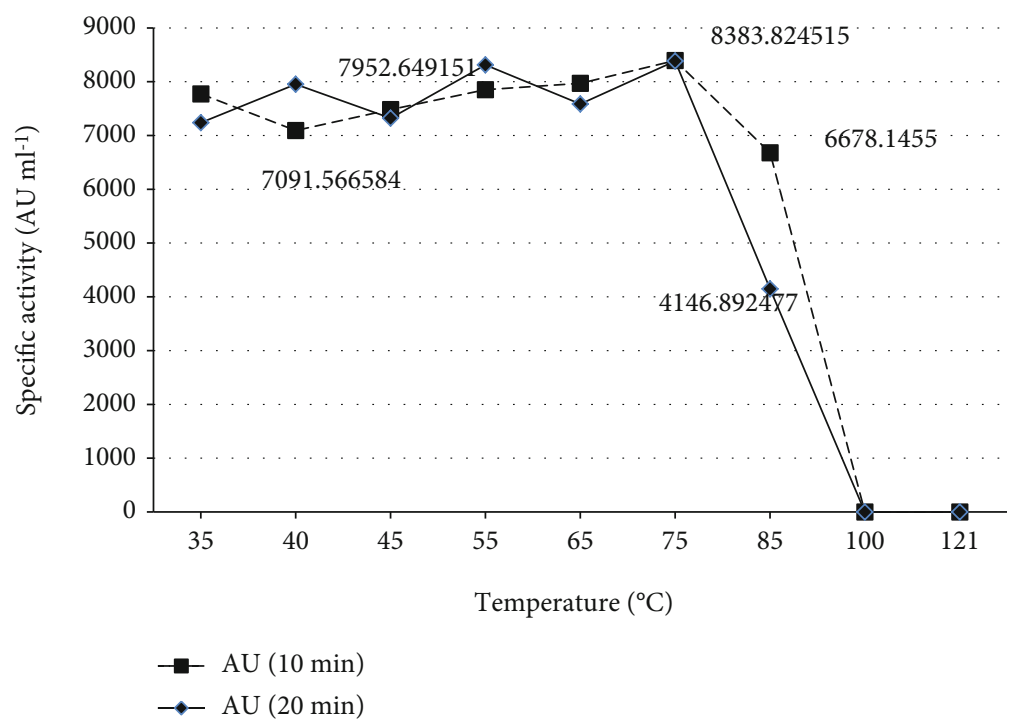

(b)

Figure 3: Continued. 




(c)

FIGURE 3: (a-c) Lifespan of antimicrobial metabolites of B.s.i. IS02 at different salinity concentrations, temperatures (for 10 and 20 minutes) and pHs. Each number is the mean of three samples taken from different treatments.

TABle 1: The growth performances of L. vannamei fed different diets supplemented with B.s.i. IS02 as probiotic for 40 days.

\begin{tabular}{lcccc}
\hline Parameters & TC & T1 & T2 & T3 \\
\hline FW (g) & $2.81 \pm 1.62^{\mathrm{a}}$ & $5.00 \pm 0.07^{\mathrm{b}}$ & $4.88 \pm 0.21^{\mathrm{b}}$ & $5.24 \pm 0.14^{\mathrm{b}}$ \\
SGR (\%/day) & $1.55 \pm 0.31^{\mathrm{a}}$ & $3.43 \pm 0.06^{\mathrm{b}}$ & $3.37 \pm 0.16^{\mathrm{b}}$ & $3.55 \pm 0.09^{\mathrm{b}}$ \\
RGR (\%) & $168.40 \pm 11.33^{\mathrm{a}}$ & $373.53 \pm 31.93^{\mathrm{b}}$ & $379.85 \pm 46.51^{\mathrm{b}}$ & $385.80 \pm 16.51^{\mathrm{b}}$ \\
SR (\%) & $60.33 \pm 6.07^{\mathrm{a}}$ & $80.00 \pm 3.32^{\mathrm{b}}$ & $84.43 \pm 5.08^{\mathrm{b}}$ & $86.10 \pm 6.31^{\mathrm{b}}$ \\
FCR & $2.63 \pm 0.26^{\mathrm{a}}$ & $1.18 \pm 0.03^{\mathrm{b}}$ & $1.18 \pm 0.11^{\mathrm{b}}$ & $1.11 \pm 0.04^{\mathrm{b}}$ \\
\hline
\end{tabular}

Note: Values are presented as mean \pm SE for three replicate groups. Same superscript words in each row indicate homogeneous subsets as determined by Duncan's test and are not significantly different $(p>.05)$. Abbreviations: $\mathrm{TC}=$ control (no probiotic provided); T1, T2, and T3 treatments received $10^{6} \mathrm{CFU} \mathrm{Kg}{ }^{-1}, 10^{7} \mathrm{CFU} \mathrm{Kg}{ }^{-1}$ and $10^{8} \mathrm{CFU} \mathrm{Kg}^{-1}$ B.s.i IS02, respectively.

\section{Discussion}

The use of functional feeds containing probiotics is considered an environment-friendly method for disease prevention in shrimp farming. The production of bacterial metabolites, especially bacteriocins, depends on a combination of different factors, especially environmental factors, such as salinity, acidity, temperature, and location or host of the isolated bacterium [19, 20,33-35]. The highest rate of antibacterial production by Bacillus subtilis KIBGE was obtained with $5 \%$ $\mathrm{NaCl}$, while it decreased by increasing the salt content [36]. The antimicrobial activities of B.s.i. IS02 metabolites were significantly different at salinity levels of $15 \%$, $25 \%$, $35 \%$, and $45 \% 0(p<.05)$; however, at 55\%o salinity, despite the suitable growth of bacteria, the antimicrobial activity of metabolites was minimal and even reached zero; it seems that $55 \%$ salinity inhibits the gene expression and production of these antimicrobial metabolites.

According to a previous study, the highest production of Sakacin P bacteriocin by Lactobacillus sakei was observed at $20^{\circ} \mathrm{C}$ [37]. Besides, the highest rates of bacteriocin production and antibacterial activity of $B$. subtilis KIBGE were reported at $37^{\circ} \mathrm{C}$ [36]. In the current study, the highest antimicrobial activity of metabolites and growth of B.s.i. IS02 was observed at $30^{\circ} \mathrm{C}$. The amount of bacterial metabolites, such as bacteriocins and biosurfactants by Bacillus strains, especially Bacillus subtilis, is higher at neutral and sometimes alkaline $\mathrm{pH}$ compared to other ranges; for example, B. subtilis KIBGE produces the greatest amount of bacteriocins at $\mathrm{pH}=7$ $[36,38-40]$. In this study, the highest specific activity of antimicrobial metabolites of B.s.i. ISO2 was observed at $\mathrm{pH}=7$, while the lowest activity was observed at $\mathrm{pH}=9$.

There are many reports on the lifespan of bacterial metabolites, especially bacteriocins under different conditions. For example, bacteriocins, produced by Bacillus thuringiensis, persist well from $4^{\circ} \mathrm{C}$ to $100^{\circ} \mathrm{C}$, while at $121^{\circ} \mathrm{C}$, their activity reaches zero [24]. In another study, it was reported that the permanence of a bacteriocin isolated from Bacillus amyloliquefaciens was inactivated at $100^{\circ} \mathrm{C}$ after 15 minutes [25]. In the present study, the antimicrobial activity of B.s.i. IS02 was well maintained in the tested ranges of salinity; the lowest level was observed at $57 \%$ salinity. However, the metabolite activity ceased at temperatures of $100^{\circ} \mathrm{C}$ and $121^{\circ} \mathrm{C}$. The antimicrobial metabolite produced by the studied bacterium decreased at $\mathrm{pH}=12$ and $\mathrm{pH}=2$, whereas no activity was reported in other $\mathrm{pH}$ ranges.

It is not clear whether probiotic candidates isolated from the host perform better than isolates from a different habitat 


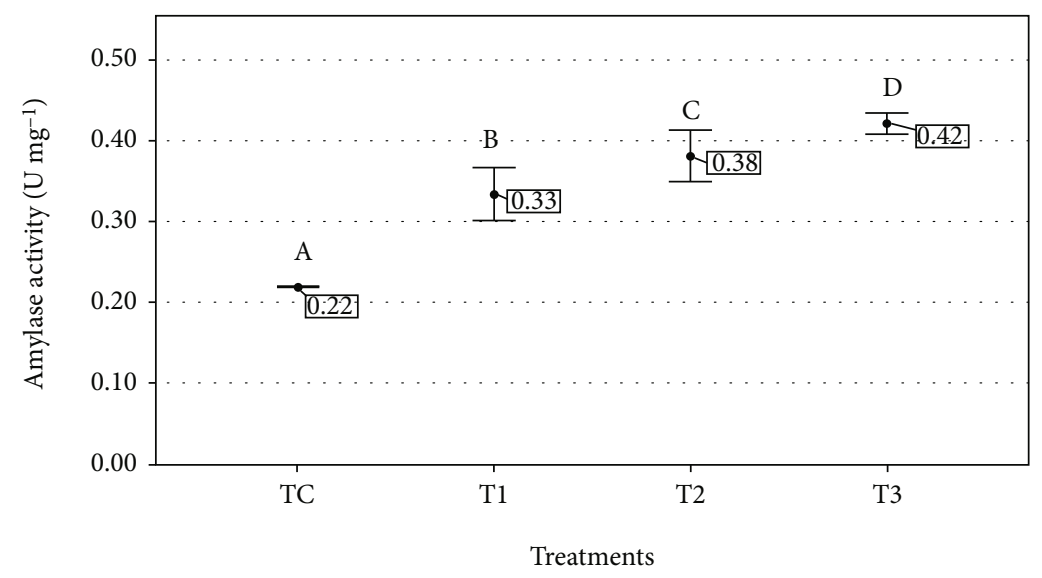

(a)

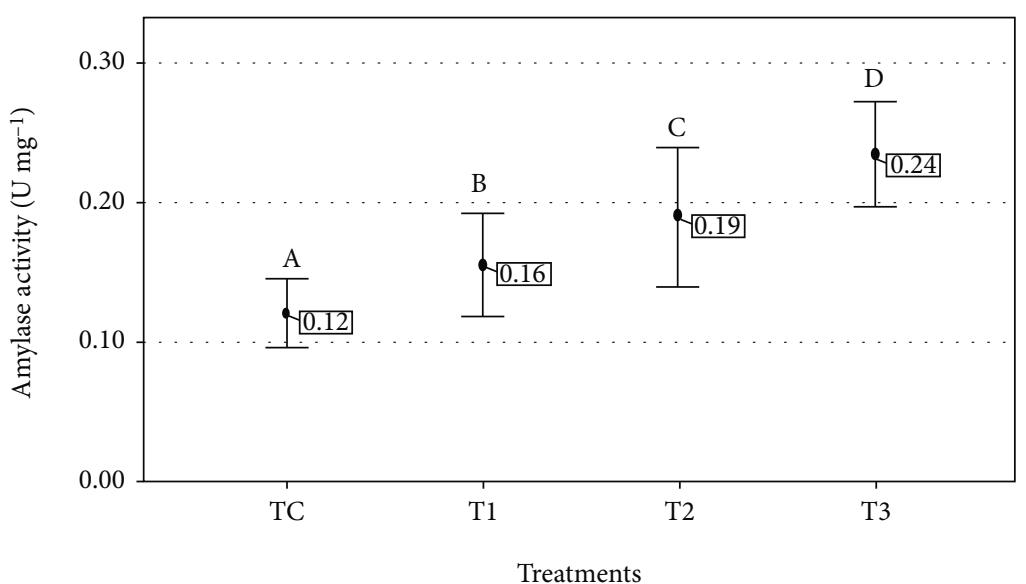

(b)

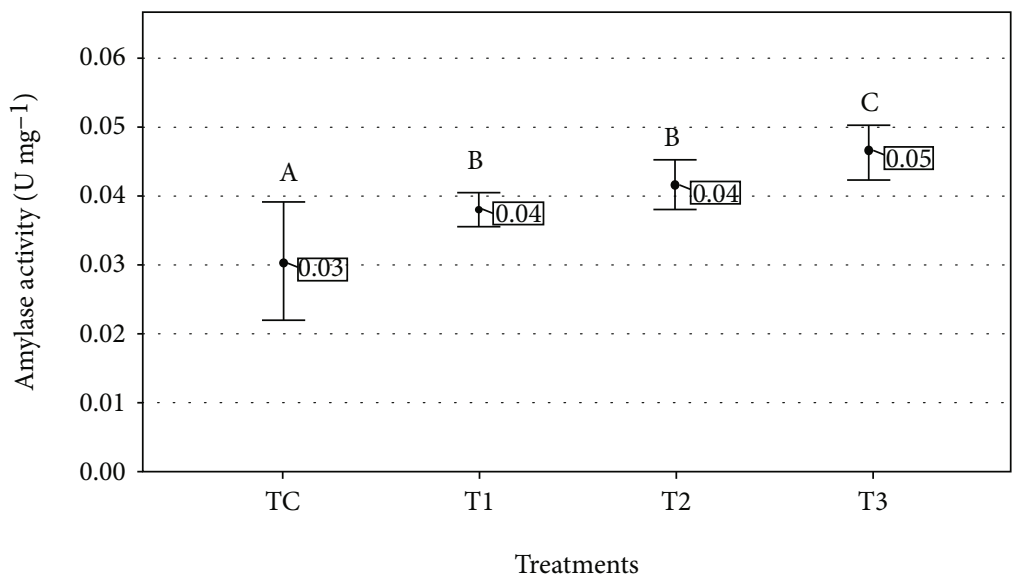

(c)

FIgUre 4: (a-c). (a) Amylase enzyme activity $\left(\mathrm{U} \mathrm{mg}^{-1}\right)$, (b) Lipase enzyme activity $\left(\mathrm{U} \mathrm{mg}^{-1}\right)$, and (c) protease enzyme activity $\left(\mathrm{U}\right.$ mg $\left.{ }^{-1}\right)$ in the intestines of L. vannamei fed with different diets supplemented of B.s.i. IS02 as probiotic for 40 days, same superscript words indicate homogeneous subsets as determined by Duncan's test and are not significantly different $(p>.05)$.

[41]; however, the host's floras are the best sites for beneficial bacteria [42]. Probiotics as functional feeds can improve the function of digestive enzymes, control the abundance of pathogenic bacteria, balance the immune system, and increase the growth parameters in aquaculture [7, 43, 44]. Various probiotics are used in shrimp farming, including the Bacillaceae family, which has been introduced by the US Food and Drug Administration (FDA) as safe microorganisms widely used in shrimp farming [45-47].

Generally, B.s.i. IS02 is a candidate probiotic isolated from the gut of cultured L. vannamei in Bushehr Province, Iran, with particular ecological conditions of high salinity 
(>35\%o) and high temperature in the shrimp farming season. In this in vivo trial, the RGR, SGR, survival rate, and activity of digestive enzymes increased at different concentrations of B.s.i. IS02 $\left(10^{6}, 10^{7}\right.$, and $\left.10^{8} \mathrm{CFU} \mathrm{kg}^{-1}\right)$, compared to the control group. In this regard, Liu et al. [48] reported that the shrimps that were fed a diet containing Bacillus subtilis E20 strain $\left(10^{8} \mathrm{CFU} \mathrm{Kg}^{-1}\right)$ had the highest survival rate, weight gain, and digestive activity of protease enzymes in the intestine versus the controls; the food conversion ratio was also significantly lower than the control group (C. H. [48]; K. F. $[49,50])$.

Likewise, the direct addition of commercial Bacillus probiotic to water increased the activity of lipase, protease, and amylase enzymes in the intestine in different growth stages of Penaeus indicus [51]. Moreover, Zokaeifar et al. [26] reported that the addition of a mixture of two $B$. subtilis strains (of equal proportion) at two different doses of $10^{5}$ CFU g ${ }^{-1}$ (BM5) and $10^{8} \mathrm{CFU} \mathrm{g}^{-1}$ (BM8) to the shrimp feed increased the final weight, weight gain, and digestive enzyme activity. In the shrimps fed with a BM8 diet, significant differences were recorded in the SGR and survival as compared to the control group; however, no significant differences were recorded for the FCR between the experimental groups [26]. In the larval and early postlarval stages of shrimp growth, the digestive system is activated, and probiotics exert the most significant effect $[28,52]$.

Bacteria, particularly members of the genus Bacillus, secrete various exoenzymes (e.g., protease, lipase, and carbohydrase), antibacterial compounds, and vitamins, which improve digestion; therefore, they significantly affect the growth and survival rate of shrimps $[13,26,53]$. Although enzymes produced by probiotics only have a small contribution to the total activity of intestinal enzymes, the presence of exogenous enzymes of probiotics may stimulate the production of digestive enzymes in shrimps. Therefore, probiotics play a vital role in improving the digestion of proteins, starch, and lipids in the shrimp gut and enhance food digestion and absorption during the farming period.

Vibrio species are one of the most critical opportunistic bacteria in shrimp farming, especially luminous Vibrio. The addition of the selected bacterial species (e.g., Bacillus sp.) to displace harmful bacteria can change the microbial composition of shrimp ponds and inhibit the growth of Vibrionaceae bacteria $[53,54]$. On the other hand, Bacillus subtilis subsp. inaquosorum, which was first identified in 2009 [55], has shown a great potential for the production of various enzymes [56], antimicrobial activity, and fungal activity [57]; in the present study, we reached a similar conclusion.

\section{Conclusion}

The selected bacteria were capable of producing antibacterial metabolites with an adequate lifespan in the typical ranges of temperature, salinity, and $\mathrm{pH}$ of shrimp pond water in the Persian Gulf and Oman Sea. Therefore, B.s.i. IS02 can be used as a suitable and beneficial probiotic and food additive to the shrimp feed, depending on the ecological conditions of the region.

\section{Data Availability}

The datasets generated during and/or analyzed during the current study are available from the corresponding author on reasonable request.

\section{Conflicts of Interest}

No competing interests are reported.

\section{Authors' Contributions}

Maryam Mirbakhsh was involved in the conceptualization, conducting experiment, and manuscript's final approval. Babak Ghaednia contributed to the sample collection and manuscript preparation. Akram Sadat Tabatabaee Bafroee was involved in the data curation.

\section{Acknowledgments}

This research project is supported by Iranian Fisheries Science Research Institute. The authors would like to thank Mr. Benjamin Holocomb and Mahdi Golshan for careful reading of the manuscript.

\section{References}

[1] P. De Schryver, T. Defoirdt, and P. Sorgeloos, "Early mortality syndrome outbreaks: a microbial management issue in shrimp farming?," PLoS Pathogens, vol. 10, no. 4, article e1003919, 2014.

[2] M. García-Bernal, R. Medina-Marrero, C. Rodríguez-Jaramillo et al., "Probiotic effect of Streptomyces spp. on shrimp (Litopenaeus vannamei) postlarvae challenged with Vibrio parahaemolyticus," Aquaculture nutrition, vol. 24, no. 2, pp. 865-871, 2018.

[3] S. J. Olmos, J. Paniagua-Michel, L. Lopez, and S. L. Ochoa, "Handbook of Marine Biotechnology," in Functional Feeds in Aquaculture, S.-K. Kim, Ed., p. 1800, Springer, NY, 2014.

[4] K. Li, T. Zheng, Y. Tian et al., "Beneficial effects of Bacillus licheniformis on the intestinal microflora and immunity of the white shrimp, Litopenaeus vannamei," Biotechnology Letters, vol. 29, no. 4, pp. 525-530, 2007.

[5] A. S. Ninawe and J. Selvin, "Probiotics in shrimp aquaculture: avenues and challenges," Critical reviews in microbiology, vol. 35 , no. 1 , pp. 43-66, 2009.

[6] T. J. Adorian, H. Jamali, H. G. Farsani et al., "Effects of probiotic bacteria Bacillus on growth performance, digestive enzyme activity, and hematological parameters of Asian sea bass, Lates calcarifer (Bloch)," Probiotics Antimicrob Proteins, vol. 11, no. 1, pp. 248-255, 2019.

[7] M. T. Jamal, I. A. Abdulrahman, M. Harbi, and S. Chithambaran, "Probiotics as alternative control measures in shrimp aquaculture: a review," Journal of Applied Biology and Biotechnology, vol. 7, no. 3, pp. 69-77, 2019.

[8] J. L. Balcazar and T. Rojas-Luna, "Inhibitory activity of probiotic Bacillus subtilis UTM 126 against Vibrio species confers protection against Vibriosis in juvenile shrimp (Litopenaeus vannamei)," Current Microbiology, vol. 55, no. 5, pp. 409412, 2007. 
[9] C. H. Chiu, Y. K. Guu, C. H. Liu, T. M. Pan, and W. Cheng, "Immune responses and gene expression in white shrimp, Litopenaeus vannamei, induced by Lactobacillus plantarum," Fish \& Shellfish Immunology, vol. 23, no. 2, pp. 364-377, 2007.

[10] S. Chumpol, D. Kantachote, P. Rattanachuay, V. Vuddhakul, T. Nitoda, and H. Kanzaki, "In vitro and in vivo selection of probiotic purple nonsulphur bacteria with an ability to inhibit shrimp pathogens: acute hepatopancreatic necrosis diseasecausing Vibrio parahaemolyticus and other vibrios," Aquaculture research, vol. 48, no. 6, pp. 3182-3197, 2017.

[11] R. Franco, L. Martín, A. Arenal et al., "Evaluation of two probiotics used during farm production of white shrimp Litopenaeus vannamei(Crustacea: Decapoda)," Aquaculture research, vol. 48, no. 4, pp. 1936-1950, 2017.

[12] B. Hostins, G. Lara, O. Decamp, D. E. Cesar, and W. Wasielesky, "Efficacy and variations in bacterial density in the gut of Litopenaeus vannamei reared in a BFT system and in clear water supplemented with a commercial probiotic mixture," Aquaculture, vol. 480, pp. 58-64, 2017.

[13] N. Sadat Hoseini Madani, T. J. Adorian, H. Ghafari Farsani, and S. H. Hoseinifar, "The effects of dietary probiotic Bacilli (Bacillus subtilis and Bacillus licheniformis) on growth performance, feed efficiency, body composition and immune parameters of whiteleg shrimp (Litopenaeus vannamei) postlarvae," Aquaculture Research, vol. 49, no. 5, pp. 1926-1933, 2018.

[14] M. B. Roberfroid, "What is beneficial for health? The concept of functional food," Food and Chemical Toxicology, vol. 37, no. 9-10, pp. 1039-1041, 1999.

[15] J. Azizpour, V. Chegini, M. Khosravi, and A. Einali, "Study of the physical oceanographic properties of the Persian Gulf, Strait of Hormuz and Gulf of Oman based on PG-GOOS CTD measurements," Journal of the Persian Gulf (Marine Science), vol. 5, no. 18, pp. 37-48, 2014.

[16] V. C. John, S. L. Coles, and A. A. Abozed, "Seasonal cycles of temperature, salinity and water masses of the western Arabian Gulf," Oceanologica Acta, vol. 13, no. 3, pp. 273-281, 1990.

[17] M. Mirbakhsh, A. Akhavansepahy, M. Afsharnasab, A. Khanafari, and M. R. Razavi, "Molecular identification of Vibrio harveyi from larval stage of Pacific white shrimp (Litopenaeus vannamei) Boone (Crustacea:Decapoda) by polymerase chain reaction and $16 \mathrm{~S}$ rDNA sequencing," Iranian Journal of Fisheries Sciences, vol. 13, no. 2, pp. 384-393, 2014.

[18] M. Mirbakhsh, A. Akhavansepahy, M. Afsharnasab, A. Khanafari, and M. R. Razavi, "Screening and evaluation of indigenous bacteria from the Persian Gulf as a probiotic and biocontrol agent against Vibrio harveyi in Litopenaeus vannamei post larvae," Iranian Journal of Fisheries Sciences, vol. 12, no. 4, pp. 873-886, 2013.

[19] A. Delgado, D. Brito, C. Peres, F. Noé-Arroyo, and A. GarridoFernández, "Bacteriocin production by Lactobacillus pentosus B96 can be expressed as a function of temperature and $\mathrm{NaCl}$ concentration," Food Microbiology, vol. 22, no. 6, pp. 521528, 2005.

[20] G. Rajaram, P. Manivasagan, B. Thilagavathi, and A. Saravanakumar, "Purification and characterization of a Bacteriocin produced by Lactobacillus lactis isolated from marine environment," Advance Journal of Food Science and Technology, vol. 2, no. 2, pp. 138-144, 2010.

[21] M. Balouiri, M. Sadiki, and S. K. Ibnsouda, "Methods for in vitro evaluating antimicrobial activity: A review," Journal of pharmaceutical analysis, vol. 6, no. 2, pp. 71-79, 2016.
[22] E. Parente, C. Brienza, M. Moles, and A. Ricciardi, "A comparison of methods for the measurement of bacteriocin activity," Journal of microbiological methods, vol. 22, no. 1, pp. 95-108, 1995.

[23] K. Pilasombut, K. Rumjuankiat, N. Ngamyeesoon, and L. N. D. Duy, "In vitro characterization of Bacteriocin produced by lactic acid bacteria isolated from Nem Chua, a traditional Vietnamese fermented pork," Korean Journal for Food Science of Animal Resources, vol. 35, no. 4, pp. 473-478, 2015.

[24] W. J. Jung, F. Mabood, A. Souleimanov et al., "Stability and antibacterial activity of bacteriocins produced by Bacillus thuringiensis and Bacillus thuringiensis spp. kurstaki," Journal of Microbiology and Biotechnology, vol. 18, no. 11, pp. 18361840, 2008.

[25] J.-H. Lim, H.-Y. Jeong, and S.-D. Kim, "Characterization of the bacteriocin J4 produced by Bacillus amyloliquefaciens J4 isolated from Korean traditional fermented soybean paste," Journal of the Korean Society for Applied Biological Chemistry, vol. 54, no. 3, pp. 468-474, 2011.

[26] H. Zokaeifar, J. L. Balcazar, C. R. Saad et al., "Effects of Bacillus subtilis on the growth performance, digestive enzymes, immune gene expression and disease resistance of white shrimp, Litopenaeus vannamei," Fish \& shellfish immunology, vol. 33, no. 4, pp. 683-689, 2012.

[27] H. K. Venkat, N. P. Sahu, and K. K. Jain, "Effect of feeding Lactobacillus-based probiotics on the gut microflora, growth and survival of postlarvae of Macrobrachium rosenbergii (de man)," Aquaculture research, vol. 35, no. 5, pp. 501-507, 2004.

[28] D. L. Lovett and D. L. Felder, "Ontogenetic change in digestive enzyme activity of larval and Postlarval white shrimp Penaeus setiferus (Crustacea, Decapoda, Penaeidae)," The Biological Bulletin, vol. 178, no. 2, pp. 144-159, 1990.

[29] P. Bernfeld and S. Colowick, Methods in enzymology, S. P. Colowick and N. O. Kaplan, Eds., academic press Inc., New York, 1955.

[30] M. L. Anson, "The estimation of pepsin, trypsin, papain,and cathepsin with hemoglobin," The Journal of General Physiology, vol. 22, no. 1, pp. 79-89, 1938.

[31] M. M. Bradford, "A rapid and sensitive method for the quantitation of microgram quantities of protein utilizing the principle of protein-dye binding," Analytical Biochemistry, vol. 72, no. 1-2, pp. 248-254, 1976.

[32] W. Mongkolthanaruk and S. Dharmsthiti, "Biodegradation of lipid-rich wastewater by a mixed bacterial consortium," International Biodeterioration and Biodegradation, vol. 50, no. 2, pp. 101-105, 2002.

[33] O. Gillor, A. Etzion, and M. A. Riley, "The dual role of bacteriocins as anti- and probiotics," Applied microbiology and biotechnology, vol. 81, no. 4, pp. 591-606, 2008.

[34] D. M. Gordon, M. A. Riley, and T. Pinou, "Temporal changes in the frequency of colicinogeny in Escherichia coli from house mice," Microbiology, vol. 144, no. 8, pp. 2233-2240, 1998.

[35] N. G. Vine, Towards the development of a protocol for the selection of probiotics in marine fish larviculture, Diss. Rhodes University, 2004.

[36] A. Ansari, A. Aman, N. N. Siddiqui, and S. Iqbal, "Bacteriocin (BAC-IB17): screening, isolation and production from Bacillus subtilis KIBGE IB-17," Pakistan Journal of Pharmaceutical Sciences, vol. 25, no. 1, pp. 195-201, 2012.

[37] I. M. Aasen, T. Møretrø, T. Katla, L. Axelsson, and I. Storrø, "Influence of complex nutrients, temperature and $\mathrm{pH}$ on 
bacteriocin production by Lactobacillus sakei CCUG 42687," Applied Microbiology and Biotechnology, vol. 53, no. 2, pp. 159-166, 2000.

[38] S. Barlow, A. Chesson, J. D. Collins, E. Dybing, A. Flynn, and C. Fruijtier-Pölloth, "Introduction of a Qualified Presumption of Safety (QPS) approach for assessment of selected microorganisms referred to EFSA - opinion of the Scientific Committee," The EFSA Journal, vol. 5, no. 12, pp. 1-16, 2007.

[39] R. Khalil, F. Djadouni, Y. Elbahloul, and S. Omar, "The influence of cultural and physical conditions on the antimicrobial activity of bacteriocin produced by a newly isolated Bacillus megaterium 22 strain," African Journal of Food Science, vol. 3, pp. 11-22, 2009.

[40] P. Suwansukho, V. Rukachisirikul, F. Kawai, and A. H-Kittikun, "Production and applications of biosurfactant from Bacillus subtilis MUV4," Songklanakarin Journal of Science and Technology, vol. 30, no. 1, pp. 87-93, 2008.

[41] L. Verschuere, G. Rombaut, P. Sorgeloos, and W. Verstraete, "Probiotic bacteria as biological control agents in aquaculture," Microbiology and molecular biology reviews, vol. 64, no. 4, pp. 655-671, 2000.

[42] K. M. Wanka, T. Damerau, B. Costas, A. Krueger, C. Schulz, and S. Wuertz, "Isolation and characterization of native probiotics for fish farming," Bmc Microbiology, vol. 18, no. 1, p. 119, 2018.

[43] A. Kesarcodi-Watson, H. Kaspar, M. J. Lategan, and L. Gibson, "Screening for probiotics of Greenshell ${ }^{\mathrm{TM}}$ mussel larvae, Perna canaliculus, using a larval challenge bioassay," Aquaculture, vol. 296, no. 1, pp. 159-164, 2009.

[44] B. Mombelli and M. R. Gismondo, "The use of probiotics in medical practice," International Journal of Antimicrobial Agents, vol. 16, no. 4, pp. 531-536, 2000.

[45] H. Abriouel, C. M. A. P. Franz, N. B. Omar, and A. Gálvez, "Diversity and applications of Bacillus bacteriocins," FEMS microbiology reviews, vol. 35, no. 1, pp. 201-232, 2011.

[46] J. Leonel Ochoa-Solano and J. Olmos-Soto, "The functional property of Bacillus for shrimp feeds," Food microbiology, vol. 23, no. 6, pp. 519-525, 2006.

[47] R. Slepecky and E. Hemphill, "The genus Bacillus Nonmedical in Dworkin," in The Prokaryotes, S. R. M. Falkow, E. Schleifer, and K. H. Stackebrandt, Eds., vol. 4, pp. 530-562, Springer, New York, 2006.

[48] C. H. Liu, C. S. Chiu, P. L. Ho, and S. W. Wang, "Improvement in the growth performance of white shrimp, Litopenaeus vannamei, by a protease-producing probiotic, Bacillus subtilis E20, from natto," Journal of applied microbiology, vol. 107, no. 3, pp. 1031-1041, 2009.

[49] K. F. Liu, C. H. Chiu, Y. L. Shiu, W. Cheng, and C. H. Liu, "Effects of the probiotic, Bacillus subtilis E20, on the survival, development, stress tolerance, and immune status of white shrimp, Litopenaeus vannamei larvae," Fish \& Shellfish Immunology, vol. 28, no. 5-6, pp. 837-844, 2010.

[50] M. Mirbakhsh, M. Mahjoub, M. Afsharnasab, S. Kakoolaki, M. Sayyadi, and S. Hosseinzadeh, "Effects of Bacillus subtilis on the water quality, stress tolerance, digestive enzymes, growth performance, immune gene expression, and disease resistance of white shrimp (Litopenaeus vannamei) during the early hatchery period," Aquaculture International, vol. 29, no. 6, pp. 2489-2506, 2021.

[51] S. Ziaei-Nejad, M. H. Rezaei, G. A. Takami, D. L. Lovett, A.-R. Mirvaghefi, and M. Shakouri, "The effect of Bacillus spp. bacteria used as probiotics on digestive enzyme activity, survival and growth in the Indian white shrimp Fenneropenaeus indicus," Aquaculture, vol. 252, no. 2, pp. 516-524, 2006.

[52] M. S. Kamarudin, D. A. Jones, L. le Vay, and A. Z. Abidin, "Ontogenetic change in digestive enzyme activity during larval development of Macrobrachium rosenbergii," Aquaculture, vol. 123, no. 3, pp. 323-333, 1994.

[53] S. Rengpipat, A. Tunyanun, A. W. Fast, S. Piyatiratitivorakul, and P. Menasveta, "Enhanced growth and resistance to Vibrio challenge in pond-reared black tiger shrimp Penaeus monodon fed a Bacillus probiotic," Diseases of aquatic organisms, vol. 55, no. 2, pp. 169-173, 2003.

[54] T. Nakayama, H. Lu, and N. Nomura, "Inhibitory effects of Bacillus probionts on growth and toxin production of Vibrio harveyi pathogens of shrimp," Letters in applied microbiology, vol. 49, no. 6, pp. 679-684, 2009.

[55] A. P. Rooney, N. P. Price, C. Ehrhardt, J. L. Swezey, and J. D. Bannan, "Phylogeny and molecular taxonomy of the Bacillus subtilis species complex and description of Bacillus subtilis subsp. inaquosorum subsp. nov," International journal of systematic and evolutionary microbiology, vol. 59, Part 10, pp. 2429-2436, 2009.

[56] S. Regmi, H. Y. Yoo, Y. H. Choi, Y. S. Choi, J. C. Yoo, and S. W. Kim, "Prospects for bio-industrial application of an extremely alkaline Mannanase from Bacillus subtilis subsp. inaquosorum CSB31," Biotechnology Journal, vol. 12, no. 11, article 1700113, 2017.

[57] C. A. Knight, M. J. Bowman, L. Frederick, A. Day, C. Lee, and C. A. Dunlap, "The first report of antifungal lipopeptide production by a Bacillus subtilis subsp. inaquosorum strain," Microbiological research, vol. 216, pp. 40-46, 2018. 